\title{
Oral infection of neonate gerbils by Neospora caninum tachyzoites
}

\author{
Infecção oral de gerbils neonatos com taquizoítos de Neospora caninum
}

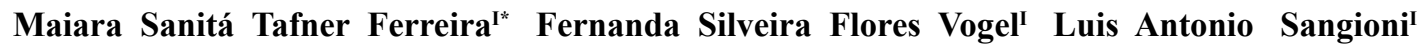
Augusto WeberI Patricia Bräunig ${ }^{I}$ Marcos André Braz Vaz ${ }^{\text {II }}$ Alfredo Skrebsky Cezar ${ }^{\text {III }}$
\end{abstract}

\section{ABSTRACT}

Neosporosis is a parasitic disease caused by the protozoan Neospora caninum which results in major economic losses for cattle breeding due to abortion and other reproductive disorders. Gerbils (Meriones unguiculatus) are commonly used as experimental models for neosporosis due to their high susceptibility to $\mathbf{N}$. caninum infection, both by oocysts ingestion as by tachyzoites/bradyzoites parenteral inoculation. However, the risk of transmission by tachyzoites ingestion is not fully elucidated. In this study, infection of neonate gerbils by $\mathbf{N}$. caninum (NC-1 strain) tachyzoites inoculated by the oral route and the parasite distribution in gerbils' tissues were evaluated by protozoan DNA detection. Seventeen neonate gerbils, aged 4-5 days, were inoculated with $4 \times 10^{5}$ tachyzoites by the oral route and one gerbil was kept as uninfected control. N. caninum DNA was detected in $100 \%$ of the inoculated gerbils, showing that the oral route is effective as a potential route of infection of neonates by $\mathbf{N}$. caninum tachyzoites. N. caninum DNA was reported in all organs evaluated (heart, lungs, kidneys, liver, spleen and brain), with different frequencies. These results showed systemically distributed infection of neonate gerbils after oral inoculation of tachyzoites.

Key words: molecular diagnosis, experimental model, bovine neosporosis, rodents.

\section{RESUMO}

Neosporose é uma doença parasitária causada pelo protozoário Neospora caninum e resulta em grandes perdas econômicas para a bovinocultura, o que se deve a abortos e outras desordens reprodutivas. Gerbils (Meriones unguiculatus) são comumente utilizados como modelos experimentais para neosporose, devido a sua alta susceptibilidade à infecção por
N. caninum, seja pela ingestão de oocistos ou pela inoculação parenteral de taquizoitos/bradizoitos. Porém, o risco de transmissão pela ingestão de taquizoitos não está totalmente elucidado. Neste estudo, foram avaliadas a infecção de gerbils neonatos por taquizoitos de $\mathbf{N}$. caninum (cepa $\mathrm{NC}$-1) inoculados por via oral e a distribuição do parasita nos tecidos desses gerbils, através da detecção de DNA do protozoário. Dezessete gerbils neonatos, com idade de 4-5 dias, foram inoculados com $4 \times 10^{5}$ taquizoítos por via oral e um gerbil foi mantido como controle nãoinfectado. DNA de N. caninum foi detectado em $100 \%$ dos gerbils inoculados, demonstrando a eficácia da via oral como potencial rota de infecção de neonatos por taquizoítos de N. caninum. DNA de $N$. caninum foi encontrado, em diferentes frequências, em todos os órgãos avaliados (coração, pulmões, rins, fígado, baço e cérebro). Esses resultados demonstraram infecção sistêmica dos gerbils neonatos após a inoculação oral de taquizoítos.

Palavras-chave: diagnóstico molecular, modelo experimental, neosporose bovina, roedores.

\section{INTRODUCTION}

Protozoan Neospora caninum (Apicomplexa) is the cosmopolitan etiologic agent of neosporosis (DUBEY et al., 2007). Canids are definitive hosts and cattle, as several mammals, are intermediate hosts of $\boldsymbol{N}$. caninum. Bovine neosporosis is characterized by embryo mortality, abortion, fetal mummification, stillbirth or birth of weak or healthy persistently infected calves, causing major losses for

\footnotetext{
ILaboratório de Doenças Parasitárias (LADOPAR), Departamento de Medicina, Veterinária Preventiva (DMVP), Universidade Federal de Santa Maria (UFSM), 97105-900, Santa Maria, RS, Brasil. E-mail: matafner@hotmail.com. ${ }^{*}$ Corresponding author.

IIDepartamento de Estatística, Centro de Ciências Naturais e Exatas (CCNE), Universidade Federal de Santa Maria (UFSM), Santa Maria, RS, Brasil.

IIIPrograma de Pós-graduação em Economia e Desenvolvimento (PPGED), Departamento de Ciências Econômicas, Centro de Ciências Sociais e Humanas (CCSH), Universidade Federal de Santa Maria (UFSM), Santa Maria, RS, Brasil.
} 
cattle industry, mainly in dairy herds (INNES et al., 2002). As proven by serology and histopathology, the birth of clinically healthy calves, congenitally infected by tachyzoites vertical transmission, allows $\boldsymbol{N}$. caninum maintenance in a herd (BARR et al., 1993, DUBEY et al., 2006). Vertical (transplacental) infection of the fetus is considered the main route of $\boldsymbol{N}$. caninum transmission in cattle (SCHARES et al., 1998), since horizontal transmission occurs by ingestion of sporulated oocysts from environment (GONDIM et al., 2004).

Natural route of horizontal infection for herbivores is the ingestion of $\boldsymbol{N}$. caninum environmental oocysts. However, small amounts of oocysts are excreted by infected dogs, hindering their collection. Thus, tachyzoites are commonly used for experimental purposes, due to their easy obtainment from in vitro cell culture (RAMAMOORTHY et al., 2005). Experimental models using rodents are desirable, since studies with cattle or dogs are expensive and demand for more time and infrastructure. Moreover, rodents can be used in studies of vaccines, drugs and strain characterization (QUINN et al., 2002).

Gerbils (Meriones unguiculatus) are excellent models for acute neosporosis, since they are highly susceptible to $\boldsymbol{N}$. caninum replication without previous immunosuppression (GONDIM et al. 2001; TONIN, et al., 2013; BOTTARI et al., 2014). Neosporosis was already reproduced in gerbils in different experimental conditions (DUBEY \& LINDSAY, 2000; GONDIM et al., 2001; RAMAMOORTHY et al., 2005; KANG et al., 2009; TOSCAN et al., 2012; TONIN et al., 2013; BOTTARI et al., 2014). Among these studies, acute infection was commonly performed by intraperitoneal inoculation of tachyzoites (CUDDON et al., 1992; RAMAMOORTHY et al., 2005; KANG et al., 2009; TOSCAN et al., 2012) and, eventually, by oral inoculation of oocysts (DUBEY \& LINDSAY 2000). Studies on N. caninum pathogenesis in gerbils are useful for development of control strategies, as vaccines or drugs, for canine and bovine neosporosis (KANG et al., 2009).

Studies indicated that bovine fetuses and neonate calves can be infected by ingestion of $\boldsymbol{N}$. caninum tachyzoites from amniotic fluid or colostrum, but specially soon after birth (DUBEY \& SHARMA 2003, ROMERO \& FRANKENA 2003, HOBSON et al., 2005). Experiments proved that calves are orally infected by caninum tachyzoites from colostrums and milk (UGGLA et al., 1998, DAVISON et al., 2001). However, the use of tachyzoites for oral infection of neonate gerbils as experimental model of neosporosis was not evaluated.

The aims of this study were (1) to evaluate potential transmission of $\boldsymbol{N}$. caninum by tachyzoites to neonate gerbils by the oral route; (2) to characterize organic distribution and identify preferable tissues used for parasite replication, using $\boldsymbol{N}$. caninum DNA detection by PCR; and (3) to establish an useful experimental model for prophylaxis and control studies on neosporosis in neonate animals.

\section{MATERIALS AND METHODS}

\section{In vitro culture of Neospora caninum tachyzoites}

N. caninum (NC-1 strain) was cultured in Vero cell monolayers, with RPMI medium (Invitrogen, Brazil), supplemented with $10 \%$ bovine fetal serum (Nutricell, Brazil), at $37^{\circ} \mathrm{C}$, saturated humidity and $5 \% \quad \mathrm{CO}_{2}$ atmosphere. Tachyzoites for inoculum were obtained after cellular suspension and disruption, and solution was decanted during $30 \mathrm{~min}$., at $4^{\circ} \mathrm{C}$, in sterile tube to diminish cell debris. Supernatant was recovered, washed once by centrifugation, resuspended and centrifuged with RPMI for tachyzoites concentration. Tachyzoites were counted using Neubauer's chamber and re-diluted with RPMI at the desired concentration.

Animals

Eighteen neonate gerbils (aged 4-5 days) from three litters of $\boldsymbol{N}$. caninum seronegative female gerbils, provided by UFSM animal facilities, were used. During pregnancy and lactation, adult and neonate gerbils were kept in controlled environment, allocated in appropriate boxes, with fresh water and pelletized food ad libitum.

\section{Inoculation}

Seventeen neonate gerbils were inoculated with $4 \times 10^{5}$ live tachyzoites per oral (as described by TOSCAN et al., 2012). Briefly, tachyzoites were diluted in $10 \mu \mathrm{L}$ saline solution and administered directly into the gerbils' mouths using $0.5-10 \mu \mathrm{L}$ pipette and sterile tip. One neonate gerbil was kept as uninfected control (Table 1).

\section{Infection monitoring}

Gerbils were daily evaluated during the experimental period. Clinical signs as lateral head tilt, rough coat, anorexia, abdominal swelling were monitored as indicative of acute neosporosis (AGUADO-MARTÍNEZ et al., 2009). 
Table 1 - Neospora caninum DNA detection in tissues of neonate gerbils (Meriones unguiculatus) after inoculation of $4 \times 10^{5}$ tachyzoites by oral route.

\begin{tabular}{|c|c|c|c|c|c|c|}
\hline Animal & Heart & Lungs & Spleen & Kidneys & Liver & $\mathrm{CNS}$ \\
\hline 1 & + & - & + & + & + & - \\
\hline 2 & + & - & + & + & + & + \\
\hline 3 & + & - & + & + & + & - \\
\hline 4 & + & + & + & + & + & + \\
\hline 5 & + & - & + & - & + & + \\
\hline 6 & + & + & + & - & + & - \\
\hline 7 & + & - & + & + & - & - \\
\hline 8 & + & + & + & + & - & - \\
\hline 9 & + & + & + & - & - & - \\
\hline 10 & + & + & - & - & - & - \\
\hline 11 & + & + & + & - & - & - \\
\hline 12 & - & - & + & - & - & - \\
\hline 13 & + & + & + & + & - & + \\
\hline 14 & + & + & + & + & - & + \\
\hline 15 & + & + & + & + & - & + \\
\hline 16 & + & + & + & + & - & + \\
\hline 17 & + & + & + & + & - & + \\
\hline $\mathrm{C}(-)^{*}$ & - & - & - & - & - & - \\
\hline Total (\%) & $16 / 17(94.1)^{\mathrm{a}}$ & $11 / 17(64.7)^{b}$ & $16 / 17(94.1)^{\mathrm{a}}$ & $11 / 17(64.7)^{b}$ & $6 / 17(35.3)^{c}$ & $8 / 17(47.0)^{b c}$ \\
\hline
\end{tabular}

C(-): negative (uninfected) control.

Different letters $(a, b, c)$ in each column indicated significant difference among the frequencies $(\mathrm{P}<0.05)$

Tissue collection

Central nervous system (brain, cerebellum and brainstem), liver, spleen, kidneys, lungs and heart were collected after spontaneous death or euthanasia from each gerbil. Uninfected control gerbil was euthanized at the end of the experimental period. Tissues were washed with sterile PBS and stored at $-20^{\circ} \mathrm{C}$ in microtubes up to DNA extraction.

DNA extraction and PCR

Genomic DNA was extracted from each sample using the Wizard $^{\circledR}$ Genomic DNA Purification Kit (Promega ${ }^{\mathrm{TM}}$, Madison, USA) according to manufacturer's recommendation. DNA samples were stored at $-20^{\circ} \mathrm{C}$ up to molecular analysis. Before the PCR, DNA concentration was evaluated using a PicoDrop microliter visible UV spectrophotometer (Picodrop, Cambridge, UK), at the absorbance level of $260 \mathrm{~nm}$.

PCR was performed using a primer set for specific amplification of N. caninum Nc-5 gene: forward (Np21), 5'CCCAGTGCGTCCAATCCTGTAAC-3'; and reverse (Np6), 5'CTCGCCAGTCAACCTACGTCTTCT-3' (YAMAGE et al., 1996). Amplification product (328bp) was evaluated by electrophoretic running in $1 \%$ agarosis gel, stained with $\mathrm{SYBR}^{\circledR}$ safe DNA gel stain (Invitrogen ${ }^{\mathrm{TM}}$, USA) and visualized under ultraviolet light. DNA samples extracted from N. caninum-infected and uninfected Vero cells were included as positive and negative controls, respectively, in each PCR.

Statistical analysis

Data were checked for normality by Shapiro-Wilk test at $95 \%$ confidence level. Since normality was not confirmed, data were analyzed by Wilcoxon-Mann-Whitney test (non-parametric) at $95 \%$ confidence level, comparing the frequencies of $\boldsymbol{N}$. caninum DNA positive samples for each tissue considering all the positive gerbils.

\section{RESULTS AND DISCUSSION}

Protozoan DNA was detected in several tissues, showing effective oral infection of neonate gerbils by $\boldsymbol{N}$. caninum tachyzoites. In addition, clinical signs of acute neosporosis were observed in all of the gerbils inoculated. These clinical signs were anorexia and decreasing body condition and occurred from five to seventeen days after inoculation. Other clinical signs of acute neosporosis, commonly reported in adult gerbils (RAMAMOORTHY et

Ciência Rural, v.46, n.4, abr, 2016. 
al., 2005; YANG et al., 2009; TONIN et al., 2014), were not reported in the neonate gerbils, indicating differences in the clinical course in neonate and adult animals. Mortality (spontaneous death or euthanasia in extremis) of neonate gerbils occurred from the eighth to seventeenth days. These results were in accordance to other studies, which showed the high susceptibility of the gerbils to $N$. caninum (DUBEY \& LINDSAY, 2000; RAMAMOORTHY et al., 2005; TONIN et al., 2013; BOTTARI et al., 2014). Uninfected control gerbil remained clinically healthy up to the end of the experimental period and was euthanized at day seventeen.

Clinical course was related with parasite distribution, since $N$. caninum DNA was found with higher frequencies in tissues from gerbils dead earlier. At necropsies, all infected neonate gerbils showed increased volume of kidneys and liver in comparison to uninfected control, as also observed by TOSCAN et al. (2012) in young gerbils. Besides, hemorrhagic lungs were observed in some of the inoculated neonate gerbils.

In this study, the presence of $N$. caninum DNA was detected in tissues from $100 \%$ of the inoculated animals (Table 1). Frequencies of parasite DNA detected by PCR were $94.1 \%(16 / 17)$ in heart and spleen; $64.7 \%(11 / 17)$ in lungs and kidneys; $47.0 \%(8 / 17)$ in CNS; and $35.3 \%(6 / 17)$ in liver samples. The presence of $N$. caninum DNA was used to describe the organic distribution of the parasite. PCR analysis was negative in all tissues from the uninfected neonate gerbil (control).

In a study performed by UGGLA et al. (1998), four calves were inoculated by the oral route with around 3 to $10 \times 10^{7} \mathrm{~N}$. caninum tachyzoites diluted in colostrum up to six hours after birth. Colostrum was administered using bottles (for two calves) or gastric tubes (for the other two calves). Both calves which received the inoculums using bottles were infected by $N$. caninum, as proven by positive serology and parasite DNA detection in the CNS by PCR. These data showed the potential transmission of $\boldsymbol{N}$. caninum to neonate calves due to ingestion of colostrum containing tachyzoites. Nevertheless, gastric micro environmental conditions could inactivate the free tachyzoites that reach the stomach (DUBEY, 1980). However, production of hydrochloric acid and enzymes is limited in neonates' gastrointestinal tract and proteolytic activity is decreased by the action of trypsin inhibitors contained in colostrum (ROY, 1990; TIZARD, 1996).

DAVISON et al. (2001) performed three experiments to evaluate oral transmission of $N$. caninum by tachyzoites in cattle. Firstly, six calves received colostrum or milk containing, approximately, $10^{7}$ tachyzoites, administered at four times using bottles (the first time up to 12 hours after birth, and other three times at weekly intervals). In the second experiment, two calves were feed with bovine placental tissue infected by $N$. caninum (bradyzoites/tachyzoites), before 12 hours after birth. In the third experiment, seven calves were breastfed by seropositive cows since one to three days up to 12 weeks after birth. Positive serology was observed in all calves in the first experiment and in one calf in the third experiment.

Results from studies with calves and, from the present study with gerbils, showed that per oral transmission by ingestion of $N$. caninum tachyzoites can occur in neonate animals. However, the experimental infection was performed with high concentration (around $10^{7}$ ) of tachyzoites administered for calves. Thus, at the field, calves can probably be episodically infected by the oral route if a high concentration of tachyzoites is present in colostrum or milk from infected cows (DAVISON et al., 2001). In this study, a concentration of $4 \times 10^{5}$ tachyzoites was enough for infection of $100 \%$ of neonate gerbils. However, further investigation is required to determinate the role of tachyzoites ingestion as a source of $\boldsymbol{N}$. caninum transmission to neonate animals. Moreover, it is not clear if the concentration of tachyzoites in colostrum or milk of infected cows could be enough high to cause neonatal infection.

The high frequency of $\boldsymbol{N}$. caninum DNA detected in gerbils showed that oral inoculation of tachyzoites resulted in effective replication and broad organic distribution of the parasite. The results of the present study with neonate gerbils are in agreement with data from LÓPEZ-PÉREZ et al. (2006) and TOSCAN et al. (2012), which detected $N$. caninum DNA in lungs, heart, spleen, liver and kidneys, during acute infection in adult gerbils. These data showed the affinity of the parasite to these organs in the early period of infection. Therefore, these are the preferable tissues for investigation of $\boldsymbol{N}$. caninum during acute infection in rodents.

Regarding tissue distribution of the parasite, KANG et al. (2009) showed that the first target-organs in $\boldsymbol{N}$. caninum acute infection were liver, spleen and kidneys and that brain tissue was the last reached by the parasite. Thus, parasite distribution frequency was: liver/spleen/kidney > heart/muscle/spinal cord/blood $>$ lung $>$ brain. In the study of TOSCAN et al. (2012), the distribution frequency was: kidney $>$ lung $>$ spleen $/$ heart $>$ liver $>$ 
brain $>$ spinal cord. In the present study, $N$. caninum tissue distribution was: heart/spleen $>$ lungs/kidneys/ brain, whilst the lowest frequency was reported in liver (but with no difference between brain and liver; $P<0.05$ ) (Table 1). These results were not fully concordant with reports of KANG et al. (2009) and TOSCAN et al. (2012). This fact may be related to the age of the animals. Neonate gerbils were, apparently, more susceptible to broad and systemic $N$. caninum infection, including brain invasion.

Gerbils immaturity is a contributive factor to $\boldsymbol{N}$. caninum infection, since neonate animals are more susceptible to neosporosis due to their restricted immune competency. Thus, oral inoculation of $4 \times 10^{5}$ tachyzoites was effective to reproduce acute neosporosis in $100 \%$ of the neonate gerbils, as an experimental model. However, there are still doubts on the concentration of tachyzoites in colostrum or milk of infected cows and the actual role of the oral route in natural transmission of neosporosis to neonate cattle, by tachyzoites ingestion. These aspects showed that further investigation is required to clarify the role of colostrum or milk in bovine neosporosis transmission.

\section{CONCLUSION}

Inoculation of $4 \times 10^{5} \mathrm{~N}$. caninum live tachyzoites by the oral route resulted in infection and clinical acute neosporosis in neonate gerbils. $\boldsymbol{N}$. caninum DNA was distributed by several tissues, including central nervous system, of these animals. This study showed that neonate gerbils can be used as experimental models to reproduce acute neosporosis by oral infection with live tachyzoites.

\section{BIOETHICHS AND BIOSECURITY COMMITTEE APPROVAL}

This study was approved by the Comissão de Ética no Uso de Animais (CEUA) of the Universidade Federal de Santa Maria (UFSM). Assent no. 052/2012.

\section{ACKNOWLEDGEMENTS}

We are very grateful to Dr. Rudi Weiblen from Preventive Medicine Veterinary Department-Virology Sector (UFSM) for the equipment availability. We also thank to Higher Education Personnel Improvement Coordination, identification number 1524508, and to the Programa Nacional de Pós-Doutorado (PNPD) of Coordenação de Aperfeiçoamento de Pessoal de Nível Superior (CAPES), identification number 20132641, by financial support. We are also grateful to Conselho Nacional de Desenvolvimento Científico e Tecnológico $(\mathrm{CNPq})$, procedure number $484223 / 2012-7$, to provide resources to this research.

\section{REFERENCES}

AGUADO-MARTÍNEZ, A. et al. Stage-specific expression of NcSAG4 as a marker of chronic Neospora caninum infection in a mouse model. Journal of Parasitology, v.136, p.757-764, 2009. Available from: <http://www.ncbi.nlm.nih. gov/pubmed/ 19402941>. Accessed: Nov. 20, 2012. doi: $10.1017 / \mathrm{S} 0031182009006076$.

BARR, B.C. et al. Congenital Neospora caninum infection in calves born from cows that had previously aborted Neospora infected fetuses: four cases (1990-1992). Journal of the American Medical Association, v.202, p.113-117, 1993. Available from: $<$ http://www.ncbi.nlm.nih.gov/pmc/articles/PMC1263819>. Accessed: Jul. 01, 2012.

BOTTARI, N.B. et al. Neospora caninum and Toxoplasma gondii: Relationship between hepatic lesions, cytological and biochemical analysis of the cavitary liquid during the acute phase of the diseases in experimental models. Experimental Parasitology, v.136, p.6873, 2014. Available from: <http://www.sciencedirect.com/science/ article/pii/S0014489413002907?np=y>. Accessed: May 14, 2015. doi: 10.1016/j.exppara.2013.11.004

CUDDON, P. et al. Neospora caninum infection in English Springer Spaniel littermates: diagnostic evaluation and organism isolation. Journal of Veterinary International Medicine, v.6, p.325-332, 1992. Available from: <http://www.ncbi.nlm.nih.gov/ pubmed/1484374>. Accessed: Apr. 11, 2015.

DAVISON, H.C. et al. Experimental studies on the transmission of Neospora caninum between cattle. Research in Veterinary Science, v.70, p.163-168, 2001. Available from: <http://www. sciencedirect.com/science/article/pii/S0034528801904576>. Accessed: Jul. 20, 2013. doi:10.1053/rvsc.2001.0457.

DUBEY, J.P. Persistence of encysted Toxoplasma gondii in caprine livers and public health significance of toxoplasmosis in goats. Journal of the American Medical Association, v.177, p.1203-1207, 1980. Available from: <http://www.cabdirect.org/ abstracts/19812263782.html;jsessionid=31EBC864234279A8299 31F3C80DC215>. Accessed: Jun. 01, 2012.

DUBEY, J.P.; LINDSAY, D.S. Gerbils (Meriones unguiculatus) are highly susceptible to oral infection with Neospora caninum oocysts. Parasitology Research, v.86, p.165-168, 2000. Available from: $<$ http://link.springer.com/article/10.1007/s00436 0050027\#page-1>. Accessed: Apr. 20, 2012. doi: 10.1007/s004360050027.

DUBEY, J.P.; SHARMA, S.P. Prolonged excretion of Toxoplasma gondii in semen of goats. American Journal of Veterinary Research, v.41, p.1-16, 2003. Available from: <http://www.ncbi. nlm.nih.gov/pubmed/7406300>. Accessed: May 30, 2013.

DUBEY, J.P. et al. Pathogenesis of bovine neosporosis. Journal of Comparative Pathology, v.134, p.267-289, 2006. Available from: <http://www.sciencedirect.com/ science/article/pii/S0021997505001350>. Accessed: Dec. 15, 2012. doi: 10.1016/j.jcpa.2005.11.004.

DUBEY, J.P. et al. Epidemiology and control of neosporosis and Neospora caninum. Clinical Microbiology Reviews, v.20, p.323-367, 2007. Available from: <http://www.researchgate. net/publication/6399369_Epidemiology_and_control_of neosporosis_and_Neospora_caninum $>$. Accessed: Dec. 20, 2014. doi: $10.1128 / \mathrm{CMR} .00031-\overline{06}$. 
GONDIM, L.F. et al. Isolation of Neospora caninum from the brain of a naturally infected dog, and production of encysted bradyzoites in gerbils. Veterinary Parasitology, v.101, p.1-7, 2001. Available from: <http://www.sciencedirect.com/science/ article/pii/S0304401701004939>. Accessed: Jul. 14, 2012. doi: 10.1016/S0304-4017(01)00493-9.

GONDIM, L.F. et al. Transplacental transmission and abortion in cows administered Neospora caninum oocysts. International Journal for Parasitology, v.90, p.1394-1400, 2004. Available from: <http://www.jstor.org/stable/3286234?seq=1\#page_scan tab_contents $>$. Accessed: Mar. 02, 2013.

HOBSON, J.C. et al. Risk factors associated with Neospora caninum abortion in Ontario Holstein dairy herds. Veterinary Parasitology, v.127, p.177-188, 2005. Available from: <http:// www.sciencedirect.com/science/article/pii/S0304401704004741>. Accessed: Jan. 26, 2013. doi: 10.1016/j.vetpar.2004.09.025.

INNES, E.A. et al. Immune responses to Neospora caninum and prospects for vaccination. Trends in Parasitology, v.18, p.497504, 2002. Available from: <http://www.sciencedirect.com/ science/article/pii/S1471492202023723>. Accessed: May 04, 2013. doi: 10.1016/S1471-4922(02)02372-3.

KANG, S.W. et al. Characterization of tissue distribution and histopathological lesions in Neospora caninum experimentally infected gerbils. Parasitology Research, v.104, p.12621268, 2009. Available from: <http://www.ncbi.nlm.nih.gov/ pubmed/19172297>. Accessed: Mar. 11, 2013. doi: 10.1007/ s00436-008-1322-8.

LÓPEZ-PÉREZ, I.C. et al. Comparative effect of Neospora caninum infection in balb/c mice at three different gestation periods. Journal of Parasitology, v.92, p.1286-1291, 2006. Available from: $<$ http://www. ncbi.nlm.nih.gov/pubmed/17304808>. Accessed: Nov. 05, 2012.

QUINN, H.E. et al. Characterization of an outbred pregnant mouse model of Neospora caninum infection. Journal of Parasitology, v.88, p.691-696, 2002. Available from: <http://www.jstor.org/ sx/3285344? seq=1\#page scan tab contents $>$. Accessed: Oct. 06, 2013.

RAMAMOORTHY, S. et al. Gerbil model of acute neosporosis Veterinary Parasitology, v.127,p.111-114, 2005. Available from: $<\mathrm{http}: /$ www.sciencedirect.com/science/article/pii/S0304401704004364>. Accessed: May 24, 2012. doi:10.1016/j.vetpar.2004.09.016.

ROMERO, J.J.; FRANKENA, K. The effect of the dam relationship on serostatus to Neospora caninum on 20 Costa Rica dairy farms. Veterinary Parasitology, v.114, p.159-171, 2003.
Available from: <http://www.sciencedirect.com/science/article/ pii/S0304401703001353>. Accessed: Oct. 11, 2013. doi:10.1016/ S0304-4017(03)00135-3.

ROY, J.H.B. The calf: management of health. 5.ed. Butterworths, Boston, MA: Butterworth Publishers, 1990. 1v. 258p.

SCHARES, G. The efficiency of vertical transmission of Neospora caninum in dairy cattle analyzed by serological techniques. Veterinary Parasitology, v.80, p.87-98, 1998. Available from: $<$ http://www.sciencedirect.com/science/article/pii/ S0304401798001952>. Accessed: Sept. 28, 2013. doi: 10.1016/ S0304-4017(98)00195-2.

TIZARD, I. An introduction to veterinary immunology. 5.ed. Philadelphia: Saunders, 1996. 531p.

TONIN, A.A. et al. Neospora caninum: Activity of cholinesterases during the acute and chronic phases of an experimental infection in gerbils. Experimental Parasitology, v.135, p.669-674, 2013. Available from: $<$ http://www.sciencedirect.com/science/article/pii/ S0014489413002671>. Accessed: May 22, 2015. doi:10.1016/j. exppara.2013.10.002.

TONIN, A.A. et al. Changes in purine levels associated with cellular brain injury in gerbils experimentally infected with Neospora caninum. Research in Veterinary Science, v.96, p.507-511, 2014. Available from: <http://www.sciencedirect. com/science/article/pii/S0034528814000526>. Accessed: Aug. 07, 2015. doi: 10.1016/j.rvsc.2014.03.004

TOSCAN, G. et al. Detection of nucleic acids in tissues of gerbils submitted to acute infection with Neospora caninum. Ciência Rural, v.42 p.1865-1872, 2012. Available from: $<$ http://www.scielo.br/scielo.php?pid=S 0103 $84782012001000024 \&$ script $=$ sci_arttext $>$. Accessed: Feb. 28, 2013. doi: $10.1590 / \mathrm{S} 0103-84782012005000079$.

UGGLA, A. et al. Oral Neospora caninum inoculation of neonatal calves. International Journal for Parasitology, v.28, p.14671472, 1998. Available from: <http://www.sciencedirect.com/ science/article/pii/S0020751998001106?np=y>. Accessed: Jun. 08, 2012. doi: 10.1016/S0020-7519(98)00110-6.

YAMAGE, M. et al. Neospora caninum: specific oligonucleotide primers for the detection of brain "cyst" DNA of experimentally infected nude mice by the polymerase chain reaction (PCR). Journal of Parasitology, v.82, p.272-279, 1996. Available from: $<$ http://www.jstor.org/stable/3284160?seq=1\#page_scan_tab_ contents>. Accessed: Jun. 22, 2013. doi: 10.2307/3284160. 